\title{
The Nature Conservation of Baikal Region: Special Natural Protected Areas System in Three Environmental Models
}

\author{
Tatyana P. Kalikhman \\ Institute of Geography of Siberian Branch of Russian Academy of Sciences, Irkutsk \\ Russia
}

\section{Introduction}

Lake Baikal is one of the most unique places on Earth. This is the oldest and deepest lake in the world. It contains $20 \%$ of the world's fresh water and is home to more than 2,000 endemic species of plants and animals. Therefore, current conservation of the waters of Lake Baikal and the surrounding region, is affecting the state of its ecosystem. In 1996, the Baikal area and its immediate surroundings were included in the list of World Natural Heritage Sites by UNESCO. In 1999, a special federal law "On protection of Lake Baikal» was passed. This is Russia's only law regarding the management of the lake and the Baikal region.

The main way to preserve, maintain and restore the biotic and landscape diversity is through territorial nature conservation. The territorial nature conservation activities are all of the efforts to protect areas of different categories, status and regimes of protection. In accordance with federal law "On specially protected natural areas», the main categories of protected areas are zapovednik (nature reserves or strictly protected areas), natural park (regionally declared), national park (federally declared), and zakaznik (refuges established at the federal and regional levels). There are also other, less significant (in terms of conservation) categories of protected areas.

The two most widely used approaches to conservation of protected areas are: the basin approach and administrative approach. The basin approach is driven by the goal of preserving the biotic and/or landscape diversity of the territory using natural boundaries of lake basin, for instance, a watershed as limits for management. For example, the special management structure (Lake Chaplain Steering Committee) was creating for protected of the transboundary Lake Champlain basin (The Lake, 1994). An administrative approach stresses the uniformity of institutional establishments and economic conditions within the territory, in particular for protected areas, such as those in Germany which are subject to separate federal lands (Bishop et al., 2002).

In the Baikal region, the basin approach covers the entire drainage basin of Lake Baikal which contains units of four administrative entities within the Russian Federation: the Buryatia Republic, the Zabaikalsky Kray, the Irkutsk Oblast' and the Tyva Republic. A significant part of the basin of Lake Baikal is in Mongolia and is beyond Russia's control. 
The basin approach takes into account the condition of ecosystems and natural conditions within the region in order to plan activities related to protection of the area.

The administrative approach seeks to standardize management of protected areas within the separate territories pertaining to Lake Baikal. The established institutional features of the Irkutsk Oblast', Buryatia Republic, and Zabaikalsky Kray are factored into protected area planning, including those related to land-use problems, the relationships of protected area regulations at federal and regional levels, in order to achieve unified management of protected areas within the administrative unit.

A new approach is proposed in this chapter. Called the integral, it is intended to overcome the shortcomings of the basin and the administrative approaches. It is known that the boundaries of natural areas and areas formed by the administrative and territorial division may not coincide. In the Baikal region an example of this mismatch is the Baikal Natural Territory (BNT). Determination of the BNT, which was defined in the aforementioned federal law, is the key to guiding its protection. There was therefore a need to identify and develop a new integral approach to overcome administrative boundaries in a single plan or to achieve harmonious administration of the surrounding territory, not just the area limited by the watershed of Lake Baikal. This chapter will discuss each of the three approaches for comparison and analysis.

\section{Basin approach to the study of ecosystems of Baikal watershed}

Natural circumstances isolated the basin of Lake Baikal as a region possessing high biotic and landscape diversity. There are the unique ecosystems, a large number of rare endemic species of flora and fauna, and numerous endangered species. In general, the ecology of the Lake Baikal basin is relatively well understood. A nearly continuous mountain chain of the periphery of the basin contributes to local endemism of the flora and fauna. On the other hand, in the basin contains the intersections of areas representing different geographical zones. There is a complex pattern of floristic-faunistic and ecosystem-typological interaction, which extends to adjacent biogeographic areas and across the northern part of the Asian continent.

The biotic and landscape diversity of Lake Baikal is determined by the latitude-zonal, provincial and elevation-zonal differentiation. Ecosystems form 3 main types of environments: tundra, taiga and steppe. Biomes of the major mountain systems have significantly greater diversity compared to adjacent plains. Typical of the Baikal basin, the overlap latitudinal-zonal and elevation-zonal patterns leads to taiga and forest-steppe ecosystems that are largely mountainous and steppes that have highland and lowland variants. Forest-steppe within the basin, in most cases, forms an almost continuous band of zonally elongated areas, southward of the taiga mountain systems. In general, forest-steppe communities differ in the maximum structural and biotic (adaptive types and forms of life) diversity (Bannikova, 1998; Gunin et al., 1998). Fauna in the steppe is apparent, but there is low diversity, and therefore the sustainability of these ecosystems in the region is low (Lavrenko et al., 1991).

The extent of the basin of Lake Baikal enables provincial biogeographic differentiation. There are differences in the flora of eastern and western parts of the basin. The main forest species are two different types of larch (Larix sibirica and Larix dahurica) and they share "Taiga Forest on the Southern Siberian" and "Baikalo-Dzhugdzhursky Taiga Forest" areas (Atlas of Transbaikalia, 1967). There is apparently no similar differentiation of fauna from 
west to east in the taiga zone. More significantly the forest-steppe zone and the river valleys beyond its borders contain forest-meadow species.

The ecosystem diversity of the basin of Lake Baikal is almost 3/4 of the continent's north without the subtropics. There are general geographic regularities of this phenomenon. The first is the placement of the basin in the middle of zonal spectrum of the continent, a dense arrangement of the zonal bands of high gradients increase aridity, the presence of high mountain systems with a full range of landscapes and ecosystems of elevation zones for the corresponding latitude and longitude intervals (Gunin et al, 1998 .)

The largest and most unique ecosystem in the basin is the Lake Baikal ecosystem. In addition to its ancient history and geological and geographical characteristics, Lake Baikal is unique in the amount of diversity and endemism of living plants and animals found there. More than 2,600 species have been cataloged and $84 \%$ of them are endemic. Of particular interest are freshwater sponges, invertebrates amphipods, and the endemic freshwater seal, which is only mammal that lives in Lake Baikal (Present and Future, 1996). The relatively large ecosystem of Lake Baikal basin can be classified as larch forest-steppe (Bannikova, 1998), meadow tansy steppe (Lavrenko et al., 1991), sandy-pebbly desert with almost no ephemera as "extreme types of desert vegetation" (Grubov, 1963).

Analysis of the ecosystem of Lake Baikal basin reveals uneven distribution in space and varying degrees of disturbance of ecosystems. Very few disturbed ecosystems are found in the high mountains (Khangai, Baikalsky, Barguzinsky, Ikatsky Ranges of the North-Baikal and Hentey-Chikoysky Highlands) or the midlands (Hentey, mountain ranges of southeastern Transbaikalia). Small populations over large areas usually do not pose a threat to natural systems. Some of these territories are part of the protected area (Huvsgul and Zabaikalsky national parks, Baikalsky, Sokhondinsky, Dzherginsky zapovedniks). The middle and lower elevations of the Lake Baikal basin are characterized by mild to moderate degrees of ecosystem disturbance. In the southeastern part of the valley, the plains and hummocky areas, disturbance is moderate and even severe. Local disturbance in the largest lowland riparian and lacustrine ecosystems and particularly in the areas of water collecting in Mongolia can be extreme.

\begin{tabular}{|r|r|r|r||}
\hline \hline Creating year & \multicolumn{1}{|c|}{ Number } & \multicolumn{1}{c|}{ Square, ha } & \multicolumn{2}{c|}{$\begin{array}{c}\text { Part of Baikal basin square in } \\
\text { Russia, \% }\end{array}$} \\
\hline before 1917 & 3 & about 150000 & 0.48 \\
\hline 1960 & 5 & 143300 & 0.45 \\
\hline 1970 & 9 & 614300 & 1.95 \\
\hline 1980 & 31 & 2033700 & 6.46 \\
\hline 1990 & 36 & 3038000 & 9.64 \\
\hline 2000 & 31 & 4748300 & 15.07 \\
\hline 2002 & 34 & 3531621 & 11.21 \\
\hline 2005 & 29 & 3293613 & 10.45 \\
\hline 2010 & 30 & 3295807 & 10.46 \\
\hline
\end{tabular}

Table 1. Changing the number and square of protected areas of the Russian part of the Lake Baikal basin 
The process of creating new protected areas in the Russian part of the basin intensified during the "perestroika" period, but stagnated over the last decade (Savenkova, 2001; Kalikhman, 2007). In the 1980's, the zapovednik Baikalo-Lensky (1986), Pribaikalsky and Zabaikalsky national parks (1986) were created. In 1981, the zakaznik Pribaikalsky in Buryatia was established. By 1990, the network of protected natural territories in the Russian section of the Baikal basin included 4 zapovedniks, 2 national parks, 24 zakazniks and about 120 registered natural monuments. The total area of protected natural areas is more than 3 million hectares, or $9 \%$ of the Russian part of the basin. In the 1990's zapovednik Dzherginsky and Tunkinsky National Park were created (Table 1).

Mongolia's part of the Lake Baikal basin contains 3 strictly protected areas (Bogdhan Uul (biosphere reserve), Khan Khentii, Hordol Sardag), 7 national parks (Noen Khangai, Terelj, Hangayn Nuruu, Huvsgul, Horgen, Khustain Nuruu and Tarvagatay Nuruu), 3 nature reserves (Batkhaan, Nagalkhaan; Hogno Khaan), 3 monuments (Bulgan Uul, Tulga Uul Togoo Uranus, and Husiyn Naiman Nuur) (Savenkova, Erdenetsetseg, 2000, 2002; Special Protected, 2000, Atlas of Mongolia, 2009). Table 2 lists the establishment and growth trends of protected areas in Mongolia.

\begin{tabular}{||c|c|c|c||}
\hline Creating year & Number & Square, ha & Part of Mongolia square, $\mathbf{0}$ \\
\hline 1778 & 1 & 41600 & 0.03 \\
\hline 1957 & 3 & 66400 & 0.04 \\
\hline 1965 & 9 & 236200 & 0.15 \\
\hline 1976 & 10 & 5547900 & 3.52 \\
\hline 1977 & 11 & 5613800 & 3.56 \\
\hline 1991 & 19 & 8793100 & 5.58 \\
\hline 1992 & 21 & 8825300 & 6.00 \\
\hline 1993 & 26 & 12629800 & 8.01 \\
\hline 1996 & 31 & 16452000 & 10.00 \\
\hline 1998 & 42 & 18251586 & 11.67 \\
\hline 2000 & 48 & 20530588 & 13.10 \\
\hline 2005 & 50 & 21370602 & 13.64 \\
\hline 2010 & 61 & 21832321 & 13.94 \\
\hline
\end{tabular}

Table 2. Increase in the number and square of protected areas in Mongolia

The distribution of protected areas in the basin of Lake Baikal uneven (Figure 1). Irkutsk Oblast's small part of the basin is almost completely covered by reserve land (Pribaikalsky National Park, zapovednik Baikalo-Lensky, and two zakasniks). This is an almost continuous strip of protected area along the northwest shore of the Lake Baikal. In the Buryatia Republic, the largest protected areas are close to Lake Baikal, while the remaining are small zakasniks. Protected areas of the Zabaikalsky Kray are small territories in square, but mainly protected the environments of the regions of rivers source.

Mongolian has more recently rapidly increased the number of units of different kinds of protected areas. In the central part of Lake Baikal basin in Mongolia, there is very little protected territory. There are only three minor areas: the Bogdhan Uul strictly protected area, and the Khorgo and Khustain Nuruu national parks. In 2003, Tuzhiyn Nars National Park was established in this part of the basin, but its effectiveness is still unknown. 


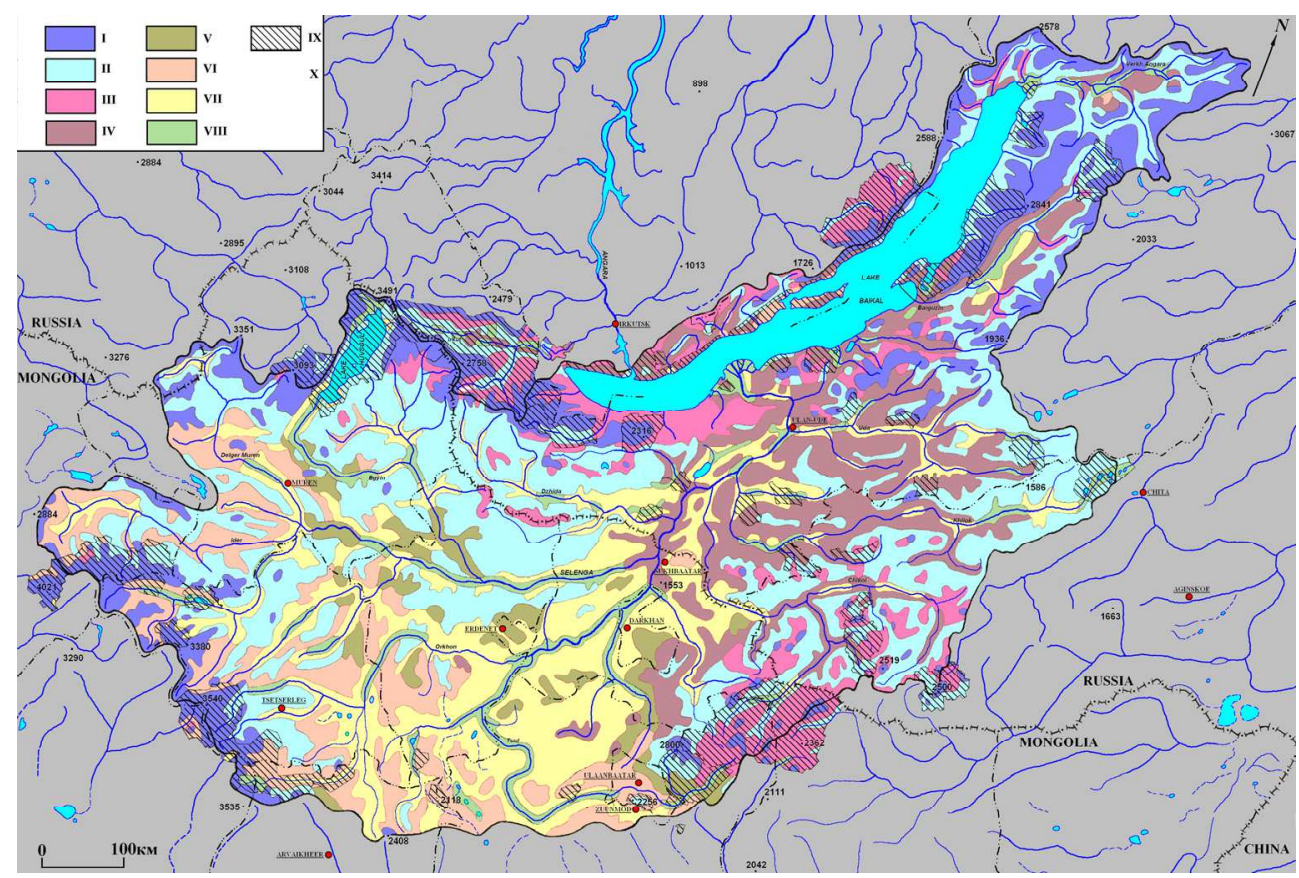

Ecosystem groups: I - high mountains wilderness and glades, II - mountains forests with larch (Larix sibirica, Larix dahurica gmelinii), III - mountains forests with cembra pine (Pinus sibirica) and fir (Abies sibirica), IV - forest with pine (Pinus silvestris), V - forest-steppe, VI - middle high mountains steppe, VII - plain or valley steppe, VIII - rivers glades; Objects: IX - special natural protected areas.

Fig. 1. Ecosystem groups and special natural protected areas in Lake Baikal basin

The uneven distribution of protected areas within the Lake Baikal basin has led to a relatively incomplete coverage of protection for different types of ecosystems (Table 3). It is evident that the most valuable in terms of biodiversity is forest-steppe. The steppe is poorly represented in the valleys of the Selenge, Orkhon, and Hilok rivers. Alpine belt ecosystems are protected only around the Lake Baikal and on the periphery of Mongolian side of the basin, as well as in adjacent Tunka Valley (Tunkinsky National Park). Typical and unique biomes are protected along the shore of Lake Baikal, except along the northern and southern lakeshores.

Thus, of the 375 different types of ecosystems identified from several sources (Belov et al, 1972; Mikheev, Ryashin, 1977; Yunnatov, Dashnyam, 1979; Ecosistems, 1995; Savenkova, 2002), only 127 (33.9\%) have been legislatively approved for conservation.

Most of protected ecosystems are in the middle- and low- elevation forests, or high-altitude glacial-nival and tundra settings. This is due to the preferential location of protected areas in the high and middle parts of the basin: Baikalsky, Barguzinsky, Baikalo-Lensky, Sokhondinsky and Dzherginsky zapovedniks and Hordol Sar'dag, Otgon Tenger, Bogdkhan Uul strictly protected areas; Hangayn Nuruu, Tarvagatay, Terelj, Huvsgul, Tunkinsky, Zabaikalsky, Pribaikalsky national parks; Angirsky, Atsinsky, Burkalsky, IvanoArakhleisky, Pribaikalsky, Snezhinsky, Uzkolugsky, Ulyunsky, Frolikhinsky zakasniks. 


\begin{tabular}{|c|c|c|c|c|c|c|c|c|c|c|}
\hline \multirow[b]{2}{*}{$\begin{array}{l}\begin{array}{r}\text { Ecosistems in } \\
\text { height-zonal } \\
\text { differentiation }\end{array} \\
\text { Variety } \\
\text { of ecosistems } \\
\text { in latitude-zonal } \\
\text { status }\end{array}$} & \multicolumn{3}{|c|}{ mountain } & \multicolumn{3}{|c|}{ plain } & \multicolumn{4}{|c|}{ hydrogenic } \\
\hline & 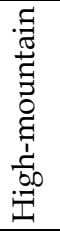 & 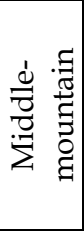 & 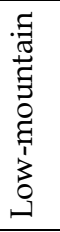 & 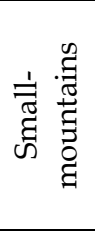 & 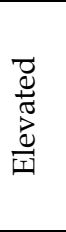 & 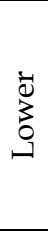 & 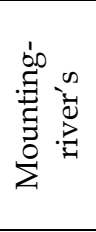 & 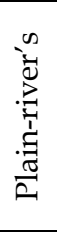 & 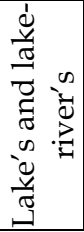 & 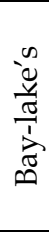 \\
\hline \multicolumn{11}{|l|}{ Zone's } \\
\hline glacial-nival & 1 & - & - & - & - & - & - & - & - & - \\
\hline $\begin{array}{l}\text { height-mountain desert } \\
\text { (tundra) }\end{array}$ & 6 & 4 & - & 1 & 2 & - & - & - & - & - \\
\hline mountain-forest & 1 & 11 & 10 & 2 & 4 & - & - & - & - & - \\
\hline forest-steppe & - & 2 & 1 & 1 & 1 & 1 & - & - & - & - \\
\hline meadow-steppe & 2 & 1 & 4 & 2 & 2 & - & - & - & - & - \\
\hline steppe & 2 & 3 & 6 & 3 & 4 & 2 & - & - & - & - \\
\hline dry-steppe & - & 3 & - & - & 2 & 1 & - & - & - & - \\
\hline $\begin{array}{l}\text { desertification- } \\
\text { steppe }\end{array}$ & - & 1 & 3 & - & 1 & 1 & - & - & - & - \\
\hline \multicolumn{11}{|l|}{ Out-of-zone's } \\
\hline $\begin{array}{l}\text { hydromorphic, } \\
\text { mountain }\end{array}$ & - & - & 1 & 2 & - & 1 & 5 & - & - & - \\
\hline $\begin{array}{l}\text { hydromorphic, } \\
\text { plain }\end{array}$ & - & - & - & - & - & - & - & 4 & 5 & 4 \\
\hline $\begin{array}{l}\text { aquatic: } \\
\text { include } \\
\text { Lake Baikal }\end{array}$ & - & - & 2 & - & - & 1 & - & - & 3 & - \\
\hline TOTAL: & 17 & 27 & 27 & 12 & 16 & 7 & 5 & 4 & 8 & 4 \\
\hline
\end{tabular}

Table 3. The number of different types of ecosystems of Lake Baikal basin, stored within the boundaries of protected areas

Left out of conservation efforts are these types of ecosystems: aquatic, including Lake Baikal itself (the only exeptions are Chivyrkuisky Bay in the Zabaikalsky National Park and the three-kilometer strip along the Barguzinsky zapovednik); forest-steppe; desert-steppe; steppe on gently undulating plateaus; hilly ridges and depressions with steppe and lacustrine communities in hydromorphic in Mongolia; and low elevation plains (including saline environments where lake-levels fluctuate).

The traditional basin approach in studying the structure of protected areas in the Baikal region can adequately reflect the effectiveness of the protected areas system in terms of coverage of the biotic and landscape diversity. But this approach ignores other important environmental features, such as political institutions and economics.

From the viewpoint of basin approach, non-uniform placement of the main categories of protected areas within the basin of Lake Baikal reveal shortcomings of the existing system of territorial environmental protection. In addition, because of the basin approach, protected areas at the periphery of the basin of Lake Baikal sometimes intersect the boundary of the 
basin. Therefore, for a complete picture must violate the principle of the basin and to include areas outside the basin in order to protect the basin.

\section{Administrative approach and consideration of the institutional features}

The administrative approach to territorial nature protection may differ significantly between regions with similar natural and socio-economic conditions. This is due to regional differences in nature conservation legislation, federal control over local politics, and the leadership of a region's head with respect to nature protection. Oftentimes, the typical and most common regional ecosystems and landscapes are overlooked. In contrast to the basin approach, the emphasis is on protecting unique and rare communities, not the unique, but commonplace. That is why in each region has created its own "Red Book", a list of rare species of animals and plants in a specific territory. However, a single institutional framework for a protected area (through legislation, administration, and economic conditions), enables consistent and coordinated efforts for nature conservation.

Two examples of the administrative approach to conservation can demonstrate the specific weaknesses this approach, as well as reveal possibilities for overcoming them through the creation of transboundary protected areas.

\subsection{Comparison of protected areas of the Irkutsk Oblast' and Krasnoyarsky Kray}

In a system of protected areas of the Irkutsk Oblast' (without the Ust-Orda Buryat autonomous district) and the Krasnoyarsky Kray (without Dolgan-Nenets and Evenk autonomous districts) one can see the following similarities: relatively large regions containing areas of pristine nature; latitudinal similarities of natural conditions wherein southern part are Sayan mountain taiga, a central taiga-covered plain (south-taiga pine forests of the Leno-Angarsky Plateau and the Yenisei Ridge) with alternating steppe and forest regions (steppe valley of the Angara and Olkhon, Achinsk and Minusinsk steppe) and northern areas of taiga in permafrost (larch forests of northern Middle Siberian Plateau in the Nizhnyaya and Podkamennaya Tunguska rivers territory); common history of development activities in the valleys of large rivers: the Kansk-Achinsk industrial area in the Krasnoyarsky Kray and the Irkutsk-Cheremhovsky industrial area in the Irkutsk Oblast' both containing open coal mines, timber production, and hydropower development; and the primary forest production areas in Russia.

Contrasts include differences in the distribution of protected areas and the area occupied by them. In the Irkutsk Oblast' the total protected area is 2048.1 thousand hectares, or $2.7 \%$ of the administrative region. In Krasnoyarsky Kray, the protected areas are uniformly distributed and comprise 3616.4 thousand hectares, or 5.1\% of the area. Lake Baikal is in the Irkutsk Oblast'. The lake is one of the largest in the world and has status of World Natural Heritage site. Thus its protection is goal of nature protection of the Irkutsk Oblast', but most of the natural areas in the region but beyond Lake Baikal are regarded as less important to the guidance of development or conservation.

Krasnoyarsky Kray adopted a regional law "On specially protected natural areas in the Krasnoyarsky Kray" immediately after the adoption of the March 1995 federal law "On specially protected natural areas". The regional law specified the following new categories of protected areas at the regional and local levels: state natural micro-reserves, state natural 
mikrozakazniks, protected wetlands, biological stations, green areas, protected water bodies, riparian zones, urban forests and urban parks. In the Irkutsk Oblast' enacted a regional law on protected areas in 2007, but did not provide any detailed regional actions, it simply adopted the provisions of the federal law.

Krasnoyarsky Kray's "Scheme development and distribution of protected areas" prioritized zakazniks as the main biodiversity preservation (mostly of individual species) mechanism in the region. In the Irkutsk Oblast', the natural park was determined to be primary protected areas units, which in addition to meeting the general goals of conservation of landscape and biotic diversity, are designed to help develop recreational resources, creating a basis for the development of ecological tourism in the region and reflect the modern world trends toward tourist access and to natural areas.

Comparative analysis of the protected areas system in the Krasnoyarsky Kray and Irkutsk Oblast' allows one make specific recommendations for measures to improve the performance of protected areas and to enable network planning (Kalikhman, Sokolov, 2005). In the Krasnoyarsky Kray, more rigorous implementation of the plan has recently motivated the reduction in number of zakazniks to preserve the beaver after sharp increase in population and observed evidence of overpopulation. Krasnoyarsky Kray protected areas are mainly intended to preservation of wildlife, but are also important for the conservation of plant communities and landscapes to support recreational resources. Irkutsk Oblast' will need to consider creation of new protected areas and to determine the mechanisms of their organization. It is extremely important to provide ways to reserve land for future protected areas as well as to balance the relationship of development to nature conservation in both the Lake Baikal basin and the rest of the region.

\subsection{National Park within the administrative boundaries}

Among Russia's Baikal protected areas the most radical form of administrative approach is in Tunkinsky National Park (TNP). Part of the park is including in the Baikal Natural Territory and is the only one in Russia organized within the administrative boundaries of the eponymous district of the Buryatia Republic. There is no evidence in the 20-years existence of TNP that there had been active protected nature within the administrative boundaries. It is clear that creation of the TNP within the administrative boundaries of the Tunkinsky district created so-called institutional contradictions or institutional overlap. These made the implementation of federal law "On specially protected natural areas" difficult, as the law declared that "National parks are unique to federal property" (Article 12, Clause 5). But TNP could not be entirely federal, because within its borders were villages, farms, private land, and resorts. The boundaries were established during Soviet times, and since then settlements were given new powers as "municipalities" and former collective and state farms became "agricultural land" which were included in the land market in line with the updated Land (2001) and Town Planning (2004) codes. TNP, based on the requirements of the federal protected-areas law, was supposed to be completely devoid of possible economic development and non-ecological land uses.

The most acceptable solution to the problem of competition between two land-users within common land borders may be the divide the land between district land and the park's land. A national park should include the lands that are most valuable for protection of ecological and landscape diversity, and for recreational use. This process should be mandatory withdrawal 
from a national park intensively used agricultural lands and territories of settlements for the effective and legitimate economic development of the district.

The logic of combining the administrative boundaries of the district and a park does not allow an optimal way to undertake nature conservation adjacent to the boundaries of the park. It is extremely important and valuable for preservation of biodiversity in areas adjacent to the Okinsky and Zakamensky districts, specifically on the northern slope of the Tunkinsky range, part of Kitoysky range and on the southern slope of the Hangarulsky ridge. These areas are also important for the effective conservation of rare species like the first migratory species to be protected: snow leopard and reindeer.

The proposed version of TNP would include areas for the conservation of rare animals species as well as mountain taiga, mountain landscapes and small areas of steppe on the northern slope of the Tunkinsky range, part of the Kitoysky range, and the Bolshoy Sayan range, which divides Russian territory from Mongolia to the west of Lake Huvsgul. This new area located north of the existing boundaries of TNP expands recreational opportunities due inclusion of popular tourist destinations: the highest point of the Vostochny Sayan mountains at Munku-Sardyk; the source of the Belyi Irkut River, Lake Ilchir, "The Valley of a hundred sources" on Shumak river at the confluence of Pravy Shumak River (108 radon, thermal and mineral sources); the valley and mountains of Arhut which bends around the northeastern part of the Tunkinsky range. The revised TNP would be more effective for environmental protection and tourism in the park, because it allows expansion of the environmental "nucleus" and recreational opportunities for visitors in the areas adjacent to the Okinsky and Zakamensky districts and removes the contradictions of the radical administrative approach to conservation (Kalikhman 2007).

\section{The integral approach within the boundaries of the BNT}

The boundaries of natural areas and administrative-territorial boundaries do not always coincide. We have considered two approaches to conservation in protected areas. The basin approach solves biodiversity and landscape preservation based on boundaries coincident with watershed boundaries. The administrative approach establishes uniformity of economic and administrative activities within the protected areas. Ways to overcome the limitations of both the basin and administrative approaches are: to establish transboundary protected areas and to create a complex nature conservation plan.

\subsection{Transboundary protected areas}

The first attempts to overcome the shortcomings of the administrative approach to the territorial nature protection are projects to organize transboundary protected areas (TBPA). A TBPA is two or more protected areas, located on both sides of a border, and having common, or at least similar, legal bases and managed through a coordinated. The principal requirements for the creation of new TBPA are the following criteria: 1 . There should be high (global) significance of territory in terms of conservation of biodiversity and ecosystems. Often this is linked to the preservation of rare species, including migratory species, distribution area which is located on the territory of neighboring states (Convention, Bonn, 23.6.1979; Agreement, Netherlands, 06/10/1996); 2. There should be good preservation as defined by common practice in similar areas; and 3 . There must be similar 
protected-areas laws and the potential for consistent decision-making for conservation in adjacent territorial units. A favorable factor is the preexistence of special natural protected areas within the territories of future TBPA (Kalikhman at al., 2005).

Transboundary protected areas allow: the avoidance territorial conflicts in nature conservation which are the main problem associated with the administrative approach and a lack of consideration of the natural boundaries of natural communities; the adopting of common or similar legal frameworks; and the organization of a single or similar management approaches in the protected areas.

The unity of the natural conditions suggests the potential creation of four TBPA between Russia and Mongolia: "From Huvsgul to Lake Baikal", "Selenga" and "Hentey-Chikoy Highlands", as well as cross-border zapovednik at the source of the Delger-Muren River at the border between the Tuva Republic and Huvsgul Aimak. It should also be noted that the TBPA "Hentey Chikoy Highlands'" could be separated into two units: "Hentey Chikoy Highlands" and "Sokhondo" (or "Source of the Amur River").

\subsection{Complex plan of nature conservation}

Another way to overcome the shortcomings of the basin and the administrative approach is to create complex regional plans for nature conservation and natural resources use. One of the most complete and comprehensive instruments for the design of a system of nature protection is a "Territorial Complex Plan of Nature Conservation of Lake Baikal" (TerCPNC Baikal), established by the act of the former USSR on 13.04.1987: "On measures to ensure the protection and rational use natural resources in the basin of Lake Baikal in 1987-1995" (Territorial, 1990). TerCPNC Baikal focused on the need for long-term conservation of the ecosystem of Lake Baikal. In addition, the plan required the pursuit of optimal solutions for socio-economic development problems and the improvement of production efficiency. TerCPNC Baikal took into account the "Standards of acceptable impacts on the ecosystem of Lake Baikal and its watershed" which had been a little earlier. The choices were determined by estimating the cost of conservation, which was comparable to the economies of the region's manufacturing industries. In even the most optimal alternative, about a third of the revenues from production in the region were to be aimed at preserving the environment. It became clear that there a lack of economic instruments for financing an effective environmental policy.

The first steps of employing TerCPNC Baikal were to analyze the degree of sensitivity of the natural ecosystems of the region to human impacts and to estimate the contribution of components of the self-regulation processes of in the complex ecosystems of the Lake Baikal and its basin. It is possible to obtain the necessary understanding of environmental regimes and the allocation of ecological zones. Carried out within the framework of the TerCPNC Baikal, ecological zoning generated three zones of regulation within the boundaries of each mode of natural resources and economic activities. Such zoning was later used to create a zoning of the BNT. Integral approach is using TerCPNC Baikal's ideas.

\subsection{The concept and principles of the BNT}

The first and only federal law that pertains to natural object is "On protection of Lake Baikal" (1999). The law requires protection of BNT. Such a task should be comprehensive and cover 
all aspects of contemporary nature conservation. Despite the framework and the declarative nature of the law, it created the opportunity to surmount the limitations and contradictions caused by the administrative boundaries or natural boundaries of the watershed of Lake Baikal for environmental management.

The BNT region was defined by the federal law: "Baikal natural territory is a territory which includes Lake Baikal, the water protection zone, adjacent to Lake Baikal and its watershed area within the territory of the Russian Federation, protected areas adjacent to Lake Baikal, and adjacent to the Lake Baikal area up to 200 kilometers to the west and north-west of it" (Chapter 1, Article 2, p.1). The enactment of the Lake Baikal law was a requirement for inclusion under World Heritage Convention of UNESCO. The convention requires that there is a single legal and management approach for the efficient operation and proper conservation of WNHS. Lake Baikal was added to the convention in 1996.

Acceptance of a BNT as defined by the federal law is the key to management of development activities relative to conservation of nature in the area. Obviously, the BNT is outside of development zones, and this allows basin or administrative approaches to be used for the analysis of environmental protection needs. Therefore for the BNT has promoted the development of an integral approach, which allows the managers to overcome the administrative segmentation of planning by creating a common or similar administration of the territory, and one not limited by natural boundaries of Lake Baikal basin.

Advantages of using an integrated approach to BNT is displayed in a territorial natureprotection model that includes ecological (its essence is represented by considering the basin approach), institutional and economic components. In this system, the wording of the institutional model of the conservation of BNT must precede the formulation of an economic model of environmental management.

\section{BPT in the institutional model of nature conservation}

The Baikal law contains a number undefined and ambiguous terms or discrepancies, of which three are most significant. The first is that the definition of BNT cannot be associated with the boundaries of WNHS "Lake Baikal". It is clear that WNHS "Lake Baikal" and BNT are different territories, though the primary objective of the law was to regulate management of the natural heritage of the region. The second discrepancy is the limited list of territories encompassed by the BNT. It is unclear whether this list includes all areas that must be in BNT, whether additions to the list are permitted, or whether it was intended only to highlight the dimensions of BNT. This ambiguity of the definition of BNT delaying the implementation of the law. A discussion of the relationship between boundaries of the central ecological zone of BNT and WNHS "Lake Baikal" lasted six years and generated no fewer than five possible conclusions. The third discrepancy is the mention of the "watershed area within the territory of the Russian Federation". The Russian's Lake Baikal basin consists of two parts, the least well-known of which is a small area located near the source of the Delger-Muren River in Tuva Republic. This river system flows into the Selenga which flows from Mongolia into Lake Baikal (Savenkova, 2001, 2002). This second area is geographically unrelated to the federal law governing the BNT. All three of these inconsistencies reflect problems with the first element of the institutional model. Correctly fixing these problems will ensure harmonization of existing and future regulations at the start and throughout the process of implementation of the law to protect Lake Baikal. 


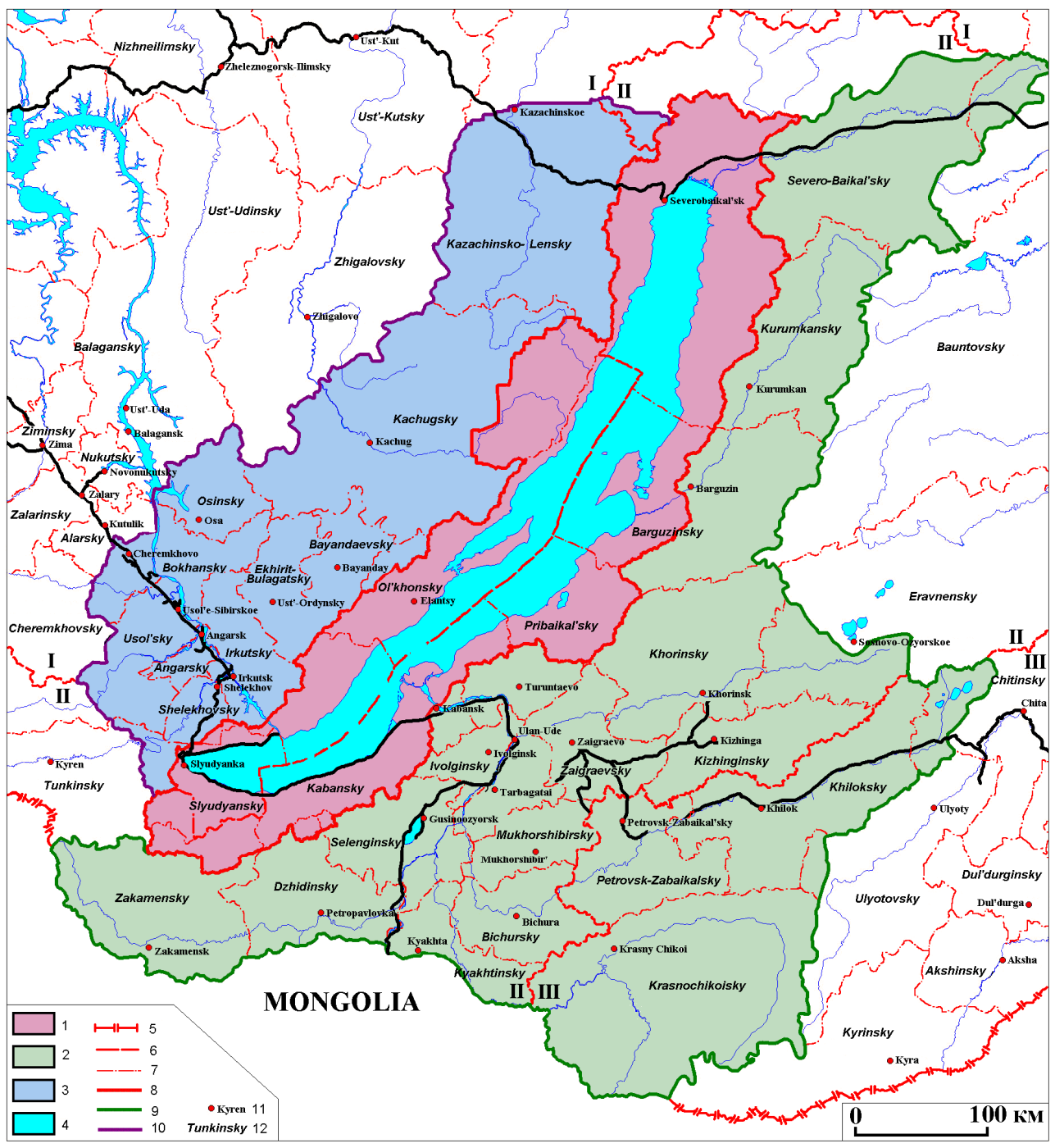

Functional ecological zones of BNT: 1 - central, 2 - buffer, 3 - of the atmosphere impact, 4 - Lake Baikal the part of the central ecological zone; Borders of: 5 - states, 6 - regions (administrative units), 7 districts (local administrative units, municipality), 8 - central ecological zone, 9 - buffer ecological zone, 10 - ecological zone of atmosphere impact; Administrative names: 11 - the centre of district (rayon), 12 district (rayon); I - Irkutsk Oblast', II - Buryatia Republic, III - Zabaikalsky Kray.

Fig. 2. Functional zoning Baikal Natural Territory 
Figure 2 shows the latest version of the location of the central ecological zone of BNT, which coincides with WNHS "Lake Baikal". The figure demonstrates a buffer zone to the southeast of the WNHS and an atmospheric influence ecological zone of to the north-west. Mapping of the zones was undertaken by the Institute of Geography of Siberian Brunch of Russian Academy of Science (RAS) in May 2006 and was approved by the Russian Government in November 2006.

Territorial planning WNHS "Lake Baikal" was determine by the activities within the protected areas within its boundaries. Within WNHS "Lake Baikal" there are 3 zapovedniks, 3 national parks, 6 zakazniks and 2 recreational areas. Over $70 \%$ of the shoreline is contained in protected areas. In addition to the WNHS "Lake Baikal" the following categories of land: "land settlement", "forest lands", "agricultural land", "land of state reserve" etc. All of these categories are distinguished as well by different levels of lands ownership: federal, regional and local.

Therefore, with regard to the institutional model of BNT and WNHS "Lake Baikal" and a new system of municipalities, consider the contradictions inherent in the relatively recent law imposed upon the boundaries and management of protected areas, settlements and agricultural enterprises that were established during the Soviet era. This conflicting circumstance reflects the second element of the institutional model, which creates the need for development of solutions to eliminate the evolutionary or sequential inconsistencies in the law and in conservation management.

\subsection{The system of special protected natural areas}

The system of special protected natural areas within the BNT at the beginning of 2006 included 5 zapovedniks, 3 national parks, 23 zakazniks and two recreational areas. Figure 3 (and table 4) shows the location of the main categories of protected areas within the BNT at the beginning of 2002 (Kalikhman, 2008 a). After 2002, the government began to reduce the total area to committed to protected areas. The reasons for reducing the number and area of protected areas are several, but are primarily associated with industrial logging. There is noteworthy absence of aquatic protected areas in the BNT on the Lake Baikal, and only a small part of the water surface of Lake Baikal is included in the existing coastal protected areas. It can be assumed if Lake Baikal's surface had been protected before the construction of the Irkutsk hydroelectric station and dam, the impact of rising the level of Lake Baikal (1958-1962) as a reservoir probably would have prevented the undertaking of the project, which has had the most significant modern impact on the ecosystems of the lake, especially those affecting fish and coastal habitats. Table 5 shows the proportion of protected areas by ecological zones in the BNT and WNHS “Lake Baikal”.

\begin{tabular}{|c|l|l|}
\hline $\begin{array}{c}\text { Number } \\
\text { protected } \\
\text { area }\end{array}$ & \multicolumn{1}{|c|}{ Name of protected area } & Notes \\
\hline \multicolumn{2}{|c|}{ Zapovedniks } \\
\hline 1 & Baikalo-Lensky & federal \\
\hline 2 & Baikalsky & federal \\
\hline 3 & Barguzinsky & federal \\
\hline 4 & Dzherginsky & federal \\
\hline 5 & Sokhondinsky & federal, part including in BNT \\
\hline
\end{tabular}




\begin{tabular}{|c|c|c|}
\hline $\begin{array}{c}\text { Number } \\
\text { protected } \\
\text { area }\end{array}$ & Name of protected area & Notes \\
\hline \multicolumn{3}{|c|}{ National parks } \\
\hline 6 & Pribaikalsky & federal \\
\hline 7 & Zabaikalsky & federal \\
\hline 8 & Tunkinsky & federal, part including in BNT \\
\hline \multicolumn{3}{|c|}{ Zakazniks } \\
\hline 9 & Altacheisky & federal \\
\hline 10 & Angirsky & regional \\
\hline 11 & Atsinsky & regional \\
\hline 12 & Atsul'sky & regional, liquidating 2002 \\
\hline 13 & Borgoisky & regional \\
\hline 14 & Burkalsky & federal \\
\hline 15 & Butungarsky & regional \\
\hline 16 & Verkhne-Angarsky & regional \\
\hline 17 & Ivano-Arakhleisky & regional \\
\hline 18 & Irkutny & regional \\
\hline 19 & Kabansky & federal \\
\hline 20 & Kochergatsky & regional \\
\hline 21 & Kurtunsky & regional, liquidating 2003 \\
\hline 22 & Kizhinginsky & regional \\
\hline 23 & Krasny Yar & federal \\
\hline 24 & Magdansky & regional \\
\hline 25 & Mokheisky & regional, liquidating 2004 \\
\hline 26 & Pribaikalsky & regional \\
\hline 27 & Ptichy (Sushinsky Kaltus) & local, liquidating 2002 \\
\hline 28 & Snezhinsky & regional \\
\hline 29 & Stepnodvoretsky & regional, liquidating 2004 \\
\hline 30 & Tagleisky & regional, liquidating 2004 \\
\hline 31 & Tugnuisky & regional \\
\hline 32 & Tukolon' & regional \\
\hline 33 & Uzkolugsky & regional \\
\hline 34 & Ulyunsky & regional \\
\hline 35 & Frolikhinsky & federal \\
\hline 36 & Khudaksky & regional \\
\hline 37 & Shirokaya Pad' & local, liquidating 2002 \\
\hline 38 & Enkhaluksky & regional \\
\hline \multicolumn{3}{|c|}{ Recreational sites } \\
\hline 39 & Baikalsky Priboi-Kultushnaya & local \\
\hline 40 & Lemasovo & local \\
\hline
\end{tabular}

Table 4. Basic categories of Special Natural Protected Areas list in Baikal Natural Territories borders 
The Nature Conservation of Baikal Region:

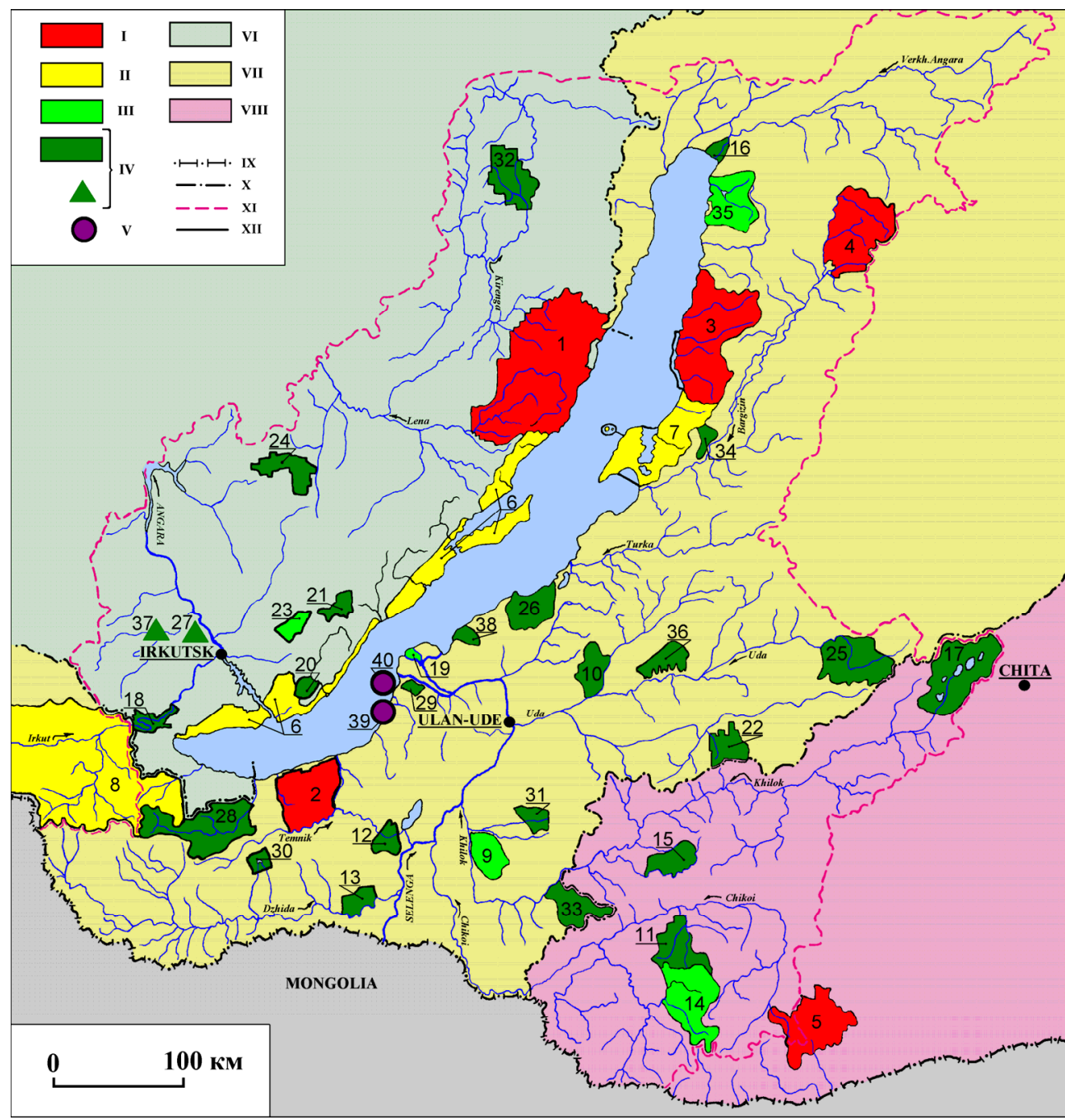

Footnote: The protected areas numeration are complying with a numeration in the table 4 .

Protected areas category:: I - zapovedniks (strictly protected areas), II - national parks, III - zakazniks (refuges) of federal meaning, IV - zakazniks (refuges) of regional and local meaning, V - recreational sites; Administrative units (subjects of Russian Federation): VI - Irkutskaya Oblast', VII - Buryatia Republic, VIII - Zabaikalsky Kray; Borders of: IX - state's, X - regions (administrative units), XI - Baikal Natural Territory, XII - protected areas.

Fig. 3. Special Protected Natural Areas of Baikal Natural Territory (the status 2002 - a year had largest area and number of protected areas) 


\begin{tabular}{|l|c|c|c|}
\hline \multicolumn{1}{|c|}{ Name of territory } & $\begin{array}{c}\text { Square of BNT } \\
\text { ecological zones, } \\
\mathrm{km}^{2}\end{array}$ & $\begin{array}{c}\text { Square of } \\
\text { protected areas, } \\
\mathrm{km}^{2}\end{array}$ & $\begin{array}{c}\text { Ratio of protected } \\
\text { areas, } \\
\%\end{array}$ \\
\hline $\begin{array}{l}\text { Central ecological zone } \\
\text { (CEZ) or WNHS "Lake }\end{array}$ & $* 89071$ & 24801 & 27,84 \\
$\begin{array}{l}\text { Baikal", include: } \\
\text { - Lake Baikal (part of CEZ) } \\
\text { - mainland (part of CEZ) }\end{array}$ & 31500 & 520 & 1,65 \\
\hline Buffer ecological zone & 213875 & 24281 & 32,18 \\
\hline $\begin{array}{l}\text { Ecological zone of } \\
\text { atmospheric influence }\end{array}$ & 83212 & 2380 & 5,36 \\
\hline $\begin{array}{l}\text { Baikal Natural Territory } \\
\text { (BNT) }\end{array}$ & 386158 & 38638 & 2,86 \\
\hline
\end{tabular}

Foot note: * The square is the result of specifying data (State report, 2006)

Table 5. The ratio of protected areas and ecological zones of BNT in 2004

WNHS "Lake Baikal" lands have a different category and status. Over $20 \%$ of the land within the boundaries of protected areas not classified as "special natural protected areas land". Institutional misunderstanding (enshrined in the federal law on protected areas) was the situation with by the liquidation of several zakazniks within the BNT. It has not led to a reduction in the amount of "special natural protected areas land" as zakasniks land are usually related to the category "forest lands".

The problem is that work on the surveying and registration of WNHS "Lake Baikal" land and protected areas land has progressed very slowly. Such work also includes a transition to a new legislative on land management system. Without such work, territorial planning and studies of the impacts of land transfer from one category to another cannot by completed. Without transfer of lands it is difficult to effectively manage either protected areas or the WNHS as a whole. The federal law "On the transfer of land or land plots from one category to another" was updated in 2005, but it did not simplify the procedures for the transfer of land and did not create a better process.

Therefore, the third element of the institutional model is a mechanism transferring land from one category (agricultural land, settlements land, land of state land's stock or "goszemzapas", etc.) to another (protected areas, recreational facilities, etc.), as well as for changing the status of land (federal, regional, local or municipal). The main obstacle to the transfer of land is a "defective" mechanism. The translation process is referred to in Art. 8 of the Land Code. The new version of the federal law on the transfer of land states that such transfer is permitted only in exceptional cases. Previously, "exceptional cases" meant only those occurring during the creation of protected areas. Now the allocation of land conservation, historical, cultural, recreational and other values is particularly valuable. The new version of the law is a formality and needs to make normative. An effective legal mechanism for transfer of land needs to be created.

In accordance with the Urban Planning Code of Russia shall be subject to special regulation of urban development "... in cases where, without introducing special rules for use of the territory ... it is impossible or difficult" (Article 6). In WNHS "Lake Baikal" objects of special 
urban planning regulations (Article 4) may be traditional territories of indigenous peoples and the settlements within the boundaries of protected areas. On the northeast shore of Lake Baikal territories traditionally inhabited by indigenous peoples are defined by the natural boundary of the Shegnanda River Evenk clan "Revival" and the area of settlement of the Evenk in the village of Kholodnaya and its surroundings.

There are 46 settlements in WNHS "Lake Baikal" within protected areas boundaries, and they may be the subject of many urban planning regulations. Only the the village Davsha of Barguzinsky zapovednik is directly involved in the activities of protected area. In addition, the boundaries of settlements in protected areas are not always clearly defined or confirmed by the Committee on Land Resources of the municipal administration. Obviously, the inclusion of settlements within the boundaries of protected areas is the result of poorly informed and poorly thought-out solutions for the organization of Pribaikalsky National Park (in 1986) and Tunkinsky National Park (in 1991). The boundaries of national parks and their functional zoning projects have been identified only in the framework of an earlier forest arrangement of the Forest Department. In the future boundaries of Pribaikalsky National Park and Tunkinsky National Park must be approved by the Russian government.

The presence of two or more types of land-users at selected sites of protected areas leads to conflicts between local communities and of protected-areas administrators. Section 3.2 has already been mentioned as producing similar problems in Tunkinsky National Park as it was organized within the administrative area (in WNHS "Lake Baikal" and BNT is 0.1 part of the park square). In this area, so-called "development zones" of settlements are not yet included in the Urban Planning Code. Therefore, the proposal to establish boundaries should encompass not only issues pertaining to settlements and guided by urban planning regulations, but also refinement and approval of the boundaries of national parks and its functional zones within territories, and providing land surveys.

Consequently, the fourth element of the institutional model is the mechanism for implementing land surveys and state registration of lands in accordance with the planning legislation.

\subsection{Planning of new protected areas}

Establishment of new protected areas in WNHS "Lake Baikal" extends protection of nature to conserve, maintain and restore biotic and landscape diversity. Among the planned protected areas within WNHS "Lake Baikal" are "natural parks" (24 out of 29 planned protected areas) (Savenkova 2001, 2002). Natural parks are most common in countries such as USA and Germany. In the state California state natural parks system are 185 units, the first was created in 1902. Only 8 national parks more larger size: Yosemite, Sequoia, King Canyon, Channel Islands, Death Valley, Joshua Tree, Redwood, and Lassen Volcanic. Common square of these categories of protected areas are comparable (Guide 2004, 2006; Ostertag R\&G, 1998). In Germany, national parks are called, in fact, natural parks, as all these protected areas are regional and are subject to the ministries of environment of individual federal lands of the country, not a federal ministry. In all there are 13 such parks in 9 of the 16 federal lands (Bishop at al., 2000).

The natural parks within WNHS "Lake Baikal" could become important components of the spatial organization of conservation, restoration and maintenance of the biodiversity and 
landscape diversity, as well as the development of recreational and tourist activities. In the Baikal region there are no natural parks, despite the many proposals that have been made. Difficulties in their creation are related to institutional conditions mentioned above. It goes without saying that this category of protected areas "natural parks" can withdraw land from existing traditional economic uses. Natural parks can have their own administration in contrast to the zakazniks and natural monuments. At the same time, smaller parks in the area are more compact and manageable compared to the national parks. Natural parks can serve as buffer between the high status of protected areas, national parks and zapovedniks, and can be established in resource development areas. It is also important that the parks can be serve the local population as well, and thus reduce the recreational load on zapovedniks and national parks. Consequently, the fifth element of the institutional model is to create natural parks, a new category of protected areas in region.

Thus, the proposed institutional model allows evaluation of the effectiveness of protected areas to conserve, maintain and restore natural systems. The use of five main elements of the model permit the development of a protected-areas system and the necessary institutional changes in the sequence of the nature protection, including: land surveying and public registration of land in all categories and types of ownership within the BNT; the establishment of borders of settlements and their "development zones"; resolution of conflicts between users of nature resources in the disputed areas of BNT; the creating a real mechanism for transferring land from one category to another for sustainable land use planning BNT; the approval by the Russian government of the boundaries of Pribaikalsky and Tunkinsky national parks with respect to the necessary use of land for agriculture and settlement; definition of recreational areas around Lake Baikal reservation and land conversion to the category of "recreational land"; and creation of a natural parks system within the BNP, which would be a new category of protected areas in Baikal region.

\section{BNT in the economic model of nature conservation}

The primary objective of activity of protected areas is to conserve biotic and landscape diversity. This objective is achieved in the process of solving relevant problems provided the expenses are adequate and economically justified. In the case of protection of nature, the economic aspect of issues to be tackled is not always amenable to straightforward and unambiguous assessment. Action to reduce biotic and landscape diversity should undergo feasibility study. Global environmental concerns are transformed in transition to regional and local level. Regional and local economic interests cannot afford to make large expenditures on behalf of nature conservation.

Such logic is evident in the BNT. The formation of BNT was constructed into account on the existing structure of nature resources using environmental and economic interests of individual actors in the region. The law "On protection of Lake Baikal" zoning BNT on the central ecological zone, buffer ecological zone, and ecological zone of atmospheric influence. The names of zones give an indication of the polarization of the interests of nature resources.

Within the BNT is valid only simple model and estimate the costs of biodiversity conservation. These estimates are based so-called "Baikal factor" can justify the receipt of federal grants for economic development and social development of the Buryat Republic and compensate for economic losses (Kalikhman, 2008 b). In environmental economics such problems have long been resolved within the concept of externalities (external effects), as 
well as factors "external (externalities) of costs" to society and future generations (Coas, 1993). But they are not applicable in Russia with a dominant resource economics.

History of the creation of protected areas within the BNT began after two reductions in the number of protected areas in 1951 and 1961. In the 1970s Baikalsky zapovednik (1969) and Sokhondinsky zapovednik (1974), Burkalsky (1978) and Kabanskiy (1967 local, since 1974 federal) federal zakazniks were created. And beginning in the mid-1980s, Baikalo-Lensky (1986) and Dzherginsky (1992) zapovedniks, Pribaikalsky (1986), Zabaikalsky (1986) and Tunkinsky (1991) national parks, and Altacheysky (1966 local, 1984 federal), Frolihinsky $(1976,1988)$ and Krasny Yar $(1994,2000)$ federal zakazniks were established.

At the same time the academic community ushered in a new global paradigm of sustainable development that now dominates the principles of environmental protection. Reflection of global trends on the national system of territorial protection of nature is presented in Table 6.

\begin{tabular}{|l|l|l|}
\hline $\begin{array}{l}\text { Areas of development } \\
\text { of activity }\end{array}$ & Traditional approaches & $\begin{array}{l}\text { Principles of sustainable } \\
\text { development }\end{array}$ \\
\hline $\begin{array}{l}\text { Strategy of utilization } \\
\text { of natural territories }\end{array}$ & $\begin{array}{l}\text { Exclusion of the maximum } \\
\text { possible area from economic } \\
\text { utilization }\end{array}$ & $\begin{array}{l}\text { Functional differentiation and } \\
\text { spatial optimization of the } \\
\text { areas of nature management }\end{array}$ \\
\hline $\begin{array}{l}\text { Strategy of } \\
\text { management of natural } \\
\text { territories }\end{array}$ & $\begin{array}{l}\text { Ideological declarative, } \\
\text { voluntarism and } \\
\text { utilitarianism }\end{array}$ & $\begin{array}{l}\text { Current normative legal base } \\
\text { with legalized pattern of land } \\
\text { use }\end{array}$ \\
\hline Economic bases & $\begin{array}{l}\text { Requirements for large } \\
\text { expenses on protection and } \\
\text { scantiness of budgetary } \\
\text { financing }\end{array}$ & $\begin{array}{l}\text { Combination of budget and } \\
\text { off-budget sources of funding }\end{array}$ \\
\hline Nature and Man & $\begin{array}{l}\text { Minimization of human } \\
\text { presence in nature }\end{array}$ & $\begin{array}{l}\text { Technological support of } \\
\text { human access to nature }\end{array}$ \\
\hline
\end{tabular}

Table 6. General trend towards the development of protected areas

\subsection{The overall economic assessment}

The main categories of protected areas, such as zapovedniks, national parks and zakazniks are state environment organizations and funded from the federal budget. Such legislation establishes the status of institutions as a mechanism of complete or partial withdrawal of these territories from economic use.

Consequently, the first element of the economic model can be considered to be the use status of protected areas by state budget organizations for solving environmental problems. The dominant of the economic model of BNT protected areas is federal budget funding, which is usually associated with the effectiveness of protected areas.

Over the past five years, funding has more than doubled. According to the Ministry of Natural Resources, only $66 \%$ of the estimated annual funding requirements for the current contents of the state natural reserves and national parks a being met.

Table 7 shows a hierarchy of tasks for the main categories of protected areas under the Federal Law "On Specially Protected Natural Areas". The problem of protection of natural 
areas to preserve biodiversity and maintain the natural environment and facilities is a priority for the main categories of protected areas. Achieving this task must be reliable and adequate funding. Therefore, the existing of $66 \%$ provision of protected areas and continued growth the budget of the protected areas can be considered satisfactory level of protection even when recognizing that there is a lack of funding.

\begin{tabular}{|l|l|l|l|}
\hline \multicolumn{1}{|c|}{ Tasks } & \multicolumn{1}{|c|}{ Zapovedniks } & National Parks & \multicolumn{1}{c|}{ Zakazniks } \\
\hline Protection of natural areas & 1 & 1 & 1 \\
\hline $\begin{array}{l}\text { Protection of historical and cultural } \\
\text { sites }\end{array}$ & - & 2 & - \\
\hline Research activity & 2 & 5 & - \\
\hline $\begin{array}{l}\text { Implementation of Environmental } \\
\text { Monitoring }\end{array}$ & 3 & 6 & 3 \\
\hline Environmental education & 4 & 3 & - \\
\hline $\begin{array}{l}\text { Participation in Environmental } \\
\text { Assessment }\end{array}$ & 5 & - & - \\
\hline Assisting in the training of scientists & 6 & - & - \\
\hline Adjustable Tourism and Leisure & - & 4 & 4 \\
\hline $\begin{array}{l}\text { Restoration of natural and cultural } \\
\text { complexes }\end{array}$ & - & 7 & 2 \\
\hline
\end{tabular}

Table 7. The priority tasks of the main categories of protected areas

Financial support for scientific activity can be considered to be at normal levels. The own research programs are supplemented by cooperative projects with staff members of academic institutions and universities in Irkutsk and Ulan-Ude as well as from other Russian and foreign research centers. Such cooperation is instrumental in enhancing the publishing and informational activities through the use of the resources provided by project participants. The success of ecological education is facilitated by the fact that the protected areas administrations are located in cities and towns, so that school and university students can be recruited as volunteers to participate in museum, exhibition and excursion activities.

In accordance with the recently firmly established system of budget and off-budget financing of protected areas $20 \%$ of the own funds are added to the $66 \%$ of the federal budget component as well as $6 \%$ are provided by local budgets, $6 \%$ by grants from international environmental foundations, and $2 \%$ are received from sponsors (Ministry, 2006).

The most marked influence on the activity of protected areas within the BNT was exerted by the Global Environment Fund (GEF) during 2000-2004 as well as its project titled "Biodiversity conservation" (Russia, Baikal component). Under these programs the Pribaikalsky National Park, for example, obtained grants in the following amounts: 550.2 thou Rbls. (2001), 74.7 thou Rbls. (2002), and 126.1 thou Rbls. (2003). During the same period the Barguzinsky, Baikalo-Lensky, Baikalsky and Dzherginsky zapovedniks obtained under GEF grants more impressive funds: from 3 to 10 mil. Rbls.

\subsection{The economy of landuse on BNT}

In recent years there has been land registration conducted by the government. To assess their own economic viability, this procedure must be applied to all protected areas. 
Protected areas on BNT are land users, and the estimates of value are based on assessments of forest and land resources. Such analyses are usually carried out once every 10 years, and if necessary more often. Table 8 shows the assessment for the main categories of protected areas. In Baikalo-Lensky zapovednik last forest inventory was carried out more then 35 years ago, over 11 years before the reserve was created. For the other protected areas, last forest inventory was carried out 10-25 years ago.

\begin{tabular}{|l|c|c|}
\hline \multirow{2}{*}{ Name of protected areas } & \multicolumn{2}{c|}{ Years of } \\
\cline { 2 - 3 } & \multicolumn{3}{|c|}{ forest arrangement } & land arrangement \\
\hline \multirow{2}{*}{ Baikalo-Lensky } & $\begin{array}{c}1975 \\
\text { (before creation of zapovednik) }\end{array}$ & -* \\
\hline Baikalsky & $1980-81$ & - \\
\hline Barguzinsky & $1980-81$ & - \\
\hline Dzherginsky & 1981 & 2004 \\
\hline Sokhondinsky & 1991 & 2003 \\
\hline \multicolumn{3}{|c|}{ National parks } \\
\hline Zabaikalsky & 1991 & - \\
\hline Pribaykalsky & 1992 & - \\
\hline Tunkinsky & 1995 & - \\
\hline \multicolumn{3}{|c|}{ Zakazniks } \\
\hline Altacheisky & $1989-1990$ & - \\
\hline Burkalsky & 2000 & - \\
\hline Frolikhinsky & $1999-2000$ & - \\
\hline Atsinsky & 2000 & - \\
\hline Ivano-Arakhleisky & 1996 & \\
\hline
\end{tabular}

*Foot note: «-» do not to made

Table 8. Carrying out the latest forest arrangement and land arrangement activities in protected areas.

Currently, the procedure of land use analysis is complemented by the work of land surveying and registration of all protected areas. The cost of surveying the land protected areas has not yet been determined. For the owners of private land, land prices based on free market value depends upon the areas in which the land is situated and unit area value. The main work in protected areas is to estimate the cost of surveying the boundaries. Ownership of the land adjacent to protected areas, outside the boundaries, is another important consideration. Federal lands dominated the BNT. It is therefore logical to transfer the costs associated with surveying to the federal budget. Thus, the second element of the economic model is the federal financing of the cost of both surveying and land and forest management in protected areas.

Within the BNP, the economy of land use in protected areas varies. The boundaries of the state nature zapovedniks approved by the Russian government transferred the lands to the category of "protected areas land". They have a federal status and have no significant settlements. Therefore there are no conflict with the local population. Pribaikalsky and Tunkinsky national parks are not approved under the Russian government borders. Their 
boundaries are consistent only with the former federal forestry service, for which they were designated. Nature has a different value, including those not derived from economic activity, and this leads to conflict. Federal zakazniks had long been in abeyance from 2004 to 2008-2009. Now, these reserves are divisions of zapovedniks or national parks. Their funding is part of the budget for zapovedniks and national parks. Regional zakazniks are found on lands of the federal forest fund, but are subordinated to the regional authorities and funded from regional budgets. The situation is different in different regions, however: in the Irkutsk Oblast', they practically unmanaged and are not financed, in Buryatia Republic and Zabaikalsky Kray the situation is more favorable.

\subsection{Recreation at BNT}

Recreational activity is not among the priorities of the protected areas, as shown in Table 7. Budgetary growth of protected areas is used to perform the basic environmental functions. Instead of differentiating the territory of protected areas based on permitted and prohibited activities, the Department of State policy in the field of environmental protection suggest transfering zapovedniks to the category of national parks. Moreover, the proposed development of the protected areas system in the direction of recreational resources and the creation of tourism infrastructure is supported. These simple ideas to increase economic activity and funding of environmental management of protected areas have been discussed above. In the irrational (non-economic) ideology of biodiversity conservation there is always a contradiction between its economic assessment on global and regional levels (Rumina, Karachevtsev, 2005).

The first attempt to study the development of recreation on the lake Baikal was undertaken in 1994 as a project commissioned by the World Bank's "Master Plan for ecotourism in the region of Lake Baikal" (The Master Plan, 1995). The basic concept of this plan are to: not exceed the maximum permissible load level of socio-economic, cultural, historical, ecological relationships in the region, including the unique communities of flora and fauna and cultural heritage; maximize opportunities and economic benefits to the local population; and maximize preservation of natural areas, national parks and reserves in the area of Lake Baikal and its waters by increasing the effectiveness of environmental stimuluses.

Since the advent of ecotourism development reports regularly promote the focus of recreational activity in protected areas. It is known that ecotourism is one of the most successful industries in the world. The formula of ecotourism in protected areas is to reduce the separation of permanent and temporary places of stay of visitors. Permanent residence refers to permanent occupation and temporary refers to the brief visits (Kalikhman at al., 2005; Shirokov at al., 2002). On BNT the recreational activities is determined by the demands for visits to Lake Baikal and the ability of protected areas to satisfy this demand. It should be noted that the proposals of quality services to stay in protected areas is extremely limited.

It is clear that extra-budgetary economy of protected areas depends directly on the flexible and operational records of demand for the visit and their competitiveness in comparison to the services for other recreational activities. Thus, the third element of the economic model is the development of recreational activities in protected areas. Such activities can satisfy the increasing demand for visits to Lake Baikal and can be used to increase funding of conservation. 


\section{Conclusion}

Specially protected natural areas of the Baikal region have typically used either the basin or administrative approach. In this chapter we propose an integral approach that allowing us to overcome shortcomings of the basin and administrative approaches. There is a need to develop an integral approach and its linked to the emergence of the law "On protection of Lake Baikal." The emergence of the law determining BNT indicates a new environmental paradigm, which is based on: the possibility of transcending the limitations and contradictions caused by the obligatory account or administrative boundaries or the boundaries of the Lake Baikal basin in environmental management; the scope of nature conservation in terms of preservation of biotic and landscape diversity the key areas on BNP with a common regulatory and legal framework similar management; and the need to transfer the emphasis from the traditional declaration of environmental regulations in the modes of regulations on the conservation of the natural environment in accordance with the purpose of ecological zones BNP. The functional model of the territorial nature protection on BNP formalizes the transition to the new environmental paradigm. Corresponding to this paradigm an integral approach to nature protection is based on the institutional and economic models, as well as a system of recreation in protected areas within the BNT and WNHS "Lake Baikal".

\section{Acknowledgment}

This study has been possible with financial support of the Russian Geographical Society, Grant N 10/06/2011.

\section{References}

Atlas of Mongolia (2009). - Ulaanbaatar. - 248 pages.

Atlas of Transbaikalia (Buryat ASSR \& Chitinskaya Oblast') (1967). - Moscow, Irkutsk: SDGK. - 176 pages.

Bannikova I.A. (1990). The structure and the function of the forest-steppe cover as a exponent natural ecosystem sustainable // Methodological aspects of the environment state valuation. - Puschino. - P.65-67.

Bardahanova T.B., Mikheyev A.S., Puntsukova S.D., Radnaev B.L. (2001). Methodology for determining the environmental costs in the region. - Ulan-Ude: Buryat Scientist Centre SB RAS. - 129 pages.

Belov A.V., Garaschenko A.V., Krotova V.M., Lapshina E.I., Peshkova G.A., Ryashin V.A., Frolova M.V. (1972). Vegetation of the Eastern Siberia south. Scale 1: 1500000. Noscow: SDGK.

Bishop K., Green M., Phillips A. (2000) Models of national parks. Moscow: Biodiversity Conservation Center, 2000. - 216 pages.

Bobylev S.N., Khodjayev A.Sh. (2003). Environmental Economics. - Moscow: Moscow State University. -567 pages.

Coas Ronald (1993) The problem of social costs // The firm, the market and right. Moscow: "Ltd". - 192 pages.

Guide to the National Parks of the United States (2006). - Washington, DC: The Book Division National Geographic Society. - 480 p. 
Guide to the State Parks of the United States (2004). - Washington, DC: The Book Division National Geographic Society. - 384 p.

Ecosystems of Mongolia: The map scale 1:1000000 (1995). Moscow - 15 pages.

Gunin P.D., Vostokova E.A., Matyushkin E.N. (1998). Protection of ecosystems in Inner Asia (1998). - Moscow: Nauka. - 221 pages.

Grubov V.I. (1963). The Central Asia botanic-geography zoning / / Plants of Central Asia. Moscow, Leningrad: USSR AS. - P. 10-69.

Kalikhman A.D., Kalikhman T.P., Khidekel V.V. (2005). Trails in natural areas of Lake Baikal. - Irkutsk: "Ottisk" - 114 pages.

Kalikhman T.P. (2007). Tunkinsky National Park, people or nature // Wildness protection, 2007 - Vol. 12 - P. 41-66.

Kalikhman T.P. (2008 a) Baikal natural territory in the institutional model of nature conservation / / Geography and Natural Resources. - N 3. - p. 65-74.

Kalikhman T.P. $(2008$ b). The Baikal natural territory in economic model of nature conservation / / Geography and Natural Resources, 2008. - N 4. - P. 330-337.

Kalikhman T.P., Sokolov V.A. (2005). The creation and the development of special protected natural areas in Irkutsk Oblast' and Krasnoyarskyy Kray // Forest rating and forest arrange. - N 2 (35). - P. 45-57.

Lavrenko E.M., Karamysheva Z.V., Nikulina R.I. (1991). Steppe of Eurasia. - Leningrad: Nauka. - 145 pages.

Mikheev V.S., Ryashin V.A. (1977). Landscapes of the Eastern Siberia south. Scale 1: 1500000. - Noscow: SDGK.

Ministry of Natural Resources (2006), http:/ / www.mnr.gov.ru

Ostertag R., Ostertag G. (1998). California State Parks. A complete recreation guide. - Seattle, WA: The Mountaineers. - 384 pages.

Rumina E.V., Karachevtsev I.L. (2005). Specificity of biodiversity conservation in the spatial and temporal aspects // Environmental Economics. - № 1. - P. 112-118.

Savenkova T.P. (2001). Protected areas of Lake Baikal basin. - Irkutsk: Institute of geography of the SB RAS. - 185 pages.

Savenkova T.P. (2002). Protected areas of Lake Baikal basin. Atlas. - Irkutsk: "Ottisk", 2002. - 96.

Savenkova T.P., Erdenetsetseg D. (2000). The protected natural areas system development in Mongolian part of Lake Baikal basin / / Geography and Natural Resources. - N 2. P. 131-138.

Savenkova T.P., Erdenetsetseg D. (2002). Spesial protected natural areas in Baikal Natural Territory / / Questions of Geography (Mongolian state university). - N 2. - P. 45-53.

Shirokov G.I., Kalikhman A.D., Komissarova N.V., Savenkova T.P. (2002) Eco-tourism: Lake Baikal. Baikal region. - Irkutsk: "Ottisk". - 192 pages.

Special protected areas of Mongolia (2000). - Ulaanbaatar. -105 pages.

State Report on Lake Baikal and measures for its protection in 2005 (2006). - Irkutsk. - 410 pages.

"Territorial Complex Plan of Nature Conservation of Lake Baikal" (TerCPNC Baikal): basic position (1990). - Moscow: Giprogor (in 2 parts). - 303 \& 403 pages.

The Lake Champlain Basin Atlas. - Burlington, VT: Northern Cartographic, 1994 - 71 p.

The Master Plan for ecotourism in the region of Lake Baikal (1995). Report for submission to the Government of Russia, under the coordination of the World Bank. - 248 pages.

Yunnatov A.A., Dashnyam B. (1979). The map of vegetation in Mongolian people republic. Scale 1: 1500000. - Moscow: SDGK. 


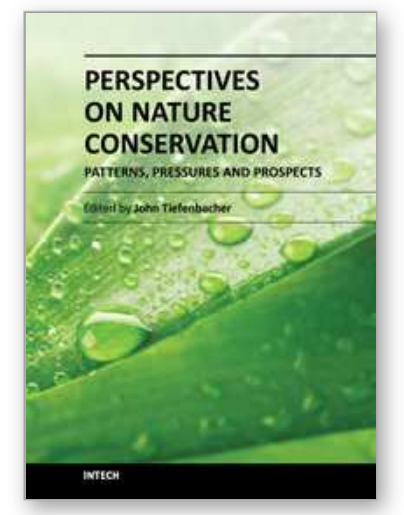

\author{
Perspectives on Nature Conservation - Patterns, Pressures and \\ Prospects \\ Edited by Prof. John Tiefenbacher
}

ISBN 978-953-51-0033-1

Hard cover, 270 pages

Publisher InTech

Published online 29, February, 2012

Published in print edition February, 2012

Perspectives on Nature Conservation demonstrates the diversity of information and viewpoints that are critical for appreciating the gaps and weaknesses in local, regional and hemispheric ecologies, and also for understanding the limitations and barriers to accomplishing critical nature conservation projects. The book is organized to emphasize the linkages between the geographic foci of conservation projects and the biological substances that we conceptualize as "nature", through original research. The reader moves through perspectives of diminishing spatial scales, from smaller to larger landscapes or larger portions of the Earth, to learn that the range of factors that promote or prevent conservation through the application of scholarship and academic concepts change with the space in question. The book reflects disciplinary diversity and a comingling of science and social science to promote understanding of the patterns of, pressures on and prospects for conservation.

\title{
How to reference
}

In order to correctly reference this scholarly work, feel free to copy and paste the following:

Tatyana P. Kalikhman (2012). The Nature Conservation of Baikal Region: Special Natural Protected Areas System in Three Environmental Models, Perspectives on Nature Conservation - Patterns, Pressures and Prospects, Prof. John Tiefenbacher (Ed.), ISBN: 978-953-51-0033-1, InTech, Available from:

http://www.intechopen.com/books/perspectives-on-nature-conservation-patterns-pressures-and-prospects/thenature-conservation-of-baikal-region-special-natural-protected-areas-system-in-three-environment

\section{INTECH}

open science | open minds

\section{InTech Europe}

University Campus STeP Ri

Slavka Krautzeka 83/A

51000 Rijeka, Croatia

Phone: +385 (51) 770447

Fax: +385 (51) 686166

www.intechopen.com

\section{InTech China}

Unit 405, Office Block, Hotel Equatorial Shanghai

No.65, Yan An Road (West), Shanghai, 200040, China

中国上海市延安西路65号上海国际贵都大饭店办公楼 405 单元

Phone: +86-21-62489820

Fax: $+86-21-62489821$ 
(C) 2012 The Author(s). Licensee IntechOpen. This is an open access article distributed under the terms of the Creative Commons Attribution 3.0 License, which permits unrestricted use, distribution, and reproduction in any medium, provided the original work is properly cited. 